\title{
Weathering of Fruchtschiefer building stones: mineral dissolution or rock disaggregation?
}

\author{
Cornelius Fischer $\cdot$ Stephan Kaufhold • \\ Wanja Wedekind • Reiner Dohrmann • \\ Volker Karius $\cdot$ Siegfried Siegesmund
}

Received: 14 January 2011 / Accepted: 18 February 2011/Published online: 5 March 2011

(C) The Author(s) 2011. This article is published with open access at Springerlink.com

\begin{abstract}
Building stones manufactured from contact metamorphic slates (Fruchtschiefer slate) from Theuma (Sachsen, Germany) were investigated for mineralogical alterations as well as for changes in porosity and surface roughness due to weathering. After weathering periods of several years to decades, the originally dark gray-colored slates show pale spots of several centimeters in size at the surface of building stones. The dark-colored and lightcolored sections of the slate show no differences in mineralogy. Surface weathering did not result in newly precipitated minerals. It was also found that the observed differences in color are not caused by variations in sedimentary organic carbon concentration or in sulfide/sulfate concentrations. Obtained results instead indicate that dark surface sections may show a thin cover of recent organic matter (OM), e.g., living OM, soot, dirt, etc. Microscopic investigations suggested that this cover was exfoliated at light-colored surface sections. The observed disaggregation of the upper $2 \mathrm{~mm}$ of the building block material results in an increase in porosity. Porosity of black (unweathered) slate is $<2 \mathrm{vol} . \%$. Due to weathering, the slate's pores with diameters $>1 \mu \mathrm{m}$ show a significant increase in frequency compared to the original pore size distribution. Porosity of weathered rock volumes increased to approx. 8 vol. $\%$. Discolored surface sections show a higher surface roughness (root-mean-square roughness, $R q \sim 1 \mu \mathrm{m}$ ) compared
\end{abstract}

C. Fischer $(\bowtie) \cdot$ W. Wedekind · V. Karius · S. Siegesmund Geowissenschaftliches Zentrum, Georg-August-Universität, Goldschmidtstr. 3, 37077 Göttingen, Germany

e-mail: cornelius.fischer@geo.uni-goettingen.de

S. Kaufhold · R. Dohrmann

Bundesanstalt für Geowissenschaften und Rohstoffe (BGR),

Landesamt für Bergbau, Energie und Geologie (LBEG),

Stilleweg 2, 30655 Hannover, Germany to dark-colored slate surfaces $(R q \sim 200 \mathrm{~nm})$, both data are for cleavage planes. Preferentially, the discolored surface sections are located close to the edges of cut stones. This and the alteration in porosity, pore size, and surface roughness indicate that color changes of the slate are largely influenced by rock disaggregation proceeding from the edges into the center rather than by mineral dissolution/ precipitation processes.

Keywords Slate weathering - Theuma Fruchtschiefer (contact slate) - Surface roughness - Rock disaggregation · Vertical scanning interferometry

\section{Introduction}

Fruchtschiefer slates from Theuma (Vogtland, Sachsen) are used as building stones (Fig. 1). Properties of the slates like high compressive strength, low water absorption, resistance against freeze/thaw action, and a good workability are ideal for building stones (e.g., Siegesmund and Snethlage 2011). The plates manufactured from Fruchtschiefer slates are used for, e.g., wall covering, tiles, floor panels, etc.

The slate is a contact metamorphic rock adjacent to the Bergen two-mica granite (Pälchen and Walter 2008). The granite belongs to the Westerzgebirge pluton (Gaitzsch et al. 2008), a late-collisional granite in the Variscan Erzgebirge (Forster et al. 1999). K-Ar age determination of the granite revealed an intrusion age of about 320-325 Ma (Gerstenberger et al. 1995). The primary rocks are Ordovician pelitic sediments and fine-grained sandstones from Phycodes formation as well as Griffelschiefer formation (Peschel and Franz 1968). Due to thermal metamorphosis adjacent to the Bergen granite, the pelites changed into 


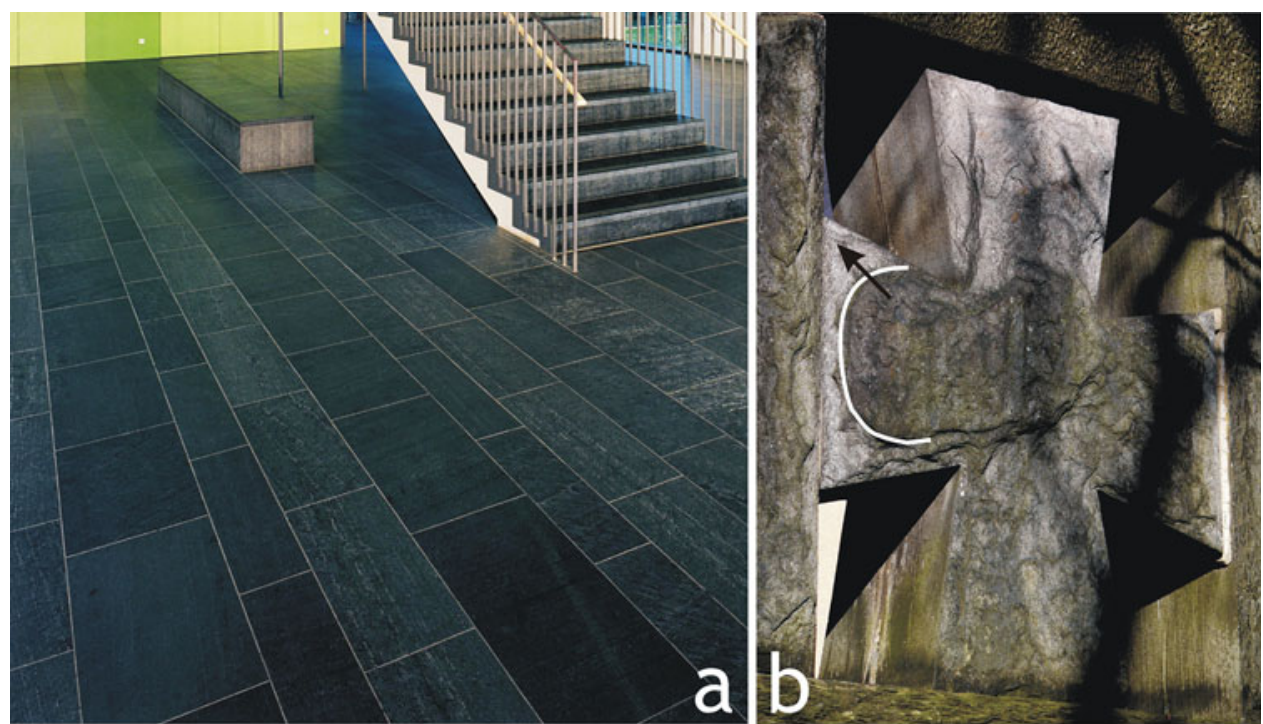

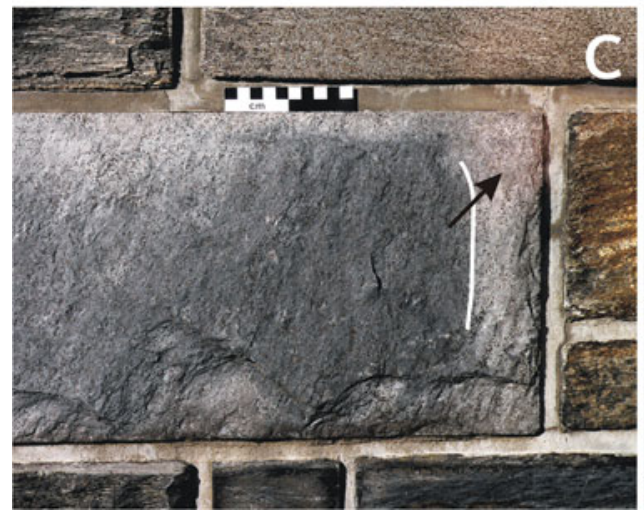

Fig. 1 a Fruchtschiefer slate from Theuma (Sachsen, Germany) is a popular material for building blocks since a long period. b Part of the war memorial (approx. 90 years old) in Theuma. The arrow indicates discolored sections at the edges of the building block. $\mathbf{c}$ The shape of discolored borders of building rocks indicates that bleaching

cordierite slates; see also the detailed information about the Bergen pluton and the respective contact metamorphic as well as retrograde metamorphic reactions in Matthes (1990). The steel gray-colored slate contains black-colored cordierite crystals or more often chlorite pseudomorphs after cordierite of several millimeters in size. Because of their characteristic shape similar to cereals, the rock is called Fruchtschiefer.

Discoloration of building rocks often indicates weathering (e.g., Siedel and Siegesmund 2011). Fruchtschiefer slates may show discolored bleached zones after several years or decades of exposition, especially close to the edges of building block plates. Discoloration was observed at floor tiles in public buildings (were the floor may experience high wear due to moisture and salt water during winter) as well as at exterior walls and at floor tiles outside of buildings. In this study, we investigate potential mineralogical and petrophysical reasons for discoloration of

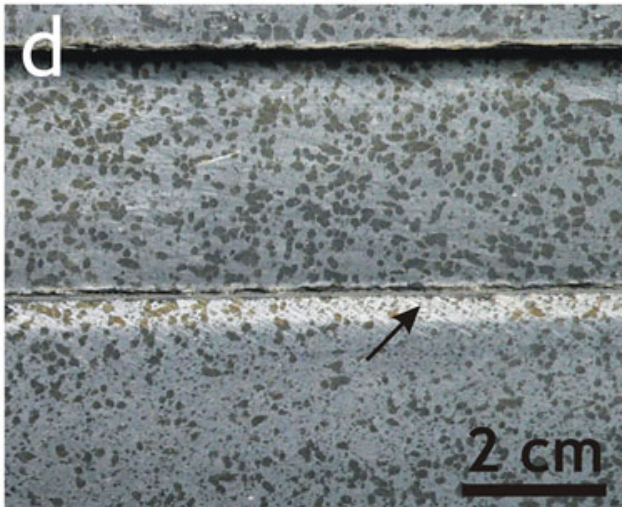

weathering proceeds from the edges into the central part of the block (arrow: discolored border). d Bleached sections at the upper part of floor tiles have a thickness of several millimeters (arrow). The floor tiles are now not embedded and were stacked for storage

Fruchtschiefer slates. Dark-colored slates may contain mature sedimentary organic matter (e.g., Zimmerle and Stribrny 1992). During oxidative weathering, even during only a few decades (Fischer et al. 2007), the amount of organic matter in black slates can decrease significantly (e.g., Fischer and Gaupp 2005; Fischer et al. 2009; Littke et al. 1991; Petsch et al. 2000). At least parts of the Fruchtschiefer slates (Matthes 1990; Peschel and Franz 1968) were formed of organic matter-bearing Ordovician Griffelschiefer (Falk and Wiefel 1995; Linnemann and Heuse 2000). One aim of this study, therefore, is to answer the question whether or not oxidation of sedimentary organic matter is responsible for discoloration of Fruchtschiefer building rocks. Knowledge about the processes of weathering, and, more specifically, knowledge about preferred weathering of components of the here discussed material could help to identify and evaluate differences in the quality of Fruchtschiefer building rocks. 
After petrographical analysis using thin-sections, both black, and discolored rock types were investigated for mineralogical and geochemical alterations. Mercury intrusion porosimetry of both types of samples was applied to detect differences in pore diameter distribution as well as differences in total porosity due to weathering. This approach allows interpretation about the predominant weathering process, e.g., rock disaggregation versus mineral dissolution/precipitation.

\section{Materials and methods}

\section{Material}

Panels of Fruchtschiefer building rocks show discolored (bleached) zones at their edges (Fig. 2). Discolored sections from the border and black sections from the center were sampled for analyses. Several sample disks (diameter 10 and $20 \mathrm{~mm}$ ) were drilled from the discolored part (e.g., section P5-B) and from the darker part (e.g., section P6-D), respectively. In addition, the surface of the dark-colored part, roughly the uppermost first millimeter, was scraped off with a sharp knife. Additionally, for investigations of the transition zone (bleached to unbleached part), a lateral profiles were sampled. Also a depth profile (surface to $5 \mathrm{~mm}, \quad 5-10 \mathrm{~mm}, \quad 10-15 \mathrm{~mm}, \quad 15-20 \mathrm{~mm}=$ bottom), starting at the bleached surface of the plate was sampled for examination of the depth of discoloration.

\section{Methods}

Thin-section petrography was performed at samples from the transition of bleached to dark rock sections (profile length: $40 \mathrm{~mm}$ ), see Fig. 2, SEM P5.

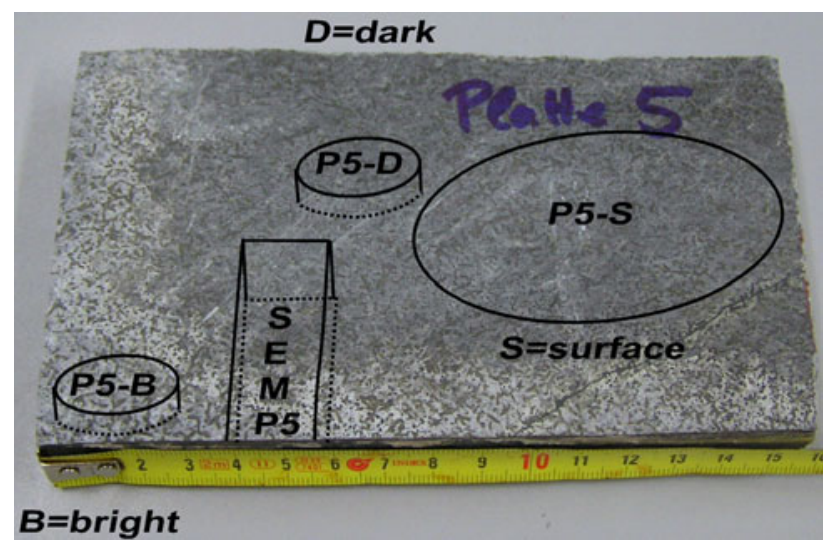

Fig. 2 Sampling strategy of the representative "plate 5": P5-B: bleached, discolored section, also sampled as depth profile; P5-D: dark (original) section; P5-S: surface material of dark (original) section; SEMP5: transition zone: discolored to dark profile
$\mathrm{X}$-ray diffraction patterns were recorded using a PANalytical X'Pert PRO MPD $\Theta-\Theta$ diffractometer $(\mathrm{Cu}-\mathrm{K} \alpha$ radiation generated at $40 \mathrm{kV}$ and $30 \mathrm{~mA}$ ), equipped with a variable divergence slit (20 $\mathrm{mm}$ irradiated length), primary and secondary soller, Scientific $\mathrm{X}^{\prime}$ Celerator detector (active length $0.59^{\circ}$ ), and a sample changer (sample diameter $28 \mathrm{~mm}$ ). The samples were investigated from $2^{\circ}$ to $85^{\circ} 2 \Theta$ with a step size of $0.0167^{\circ} 2 \Theta$ and a measuring time of $10 \mathrm{~s}$ per step. For specimen preparation the top loading technique was used. The chemical composition of powdered samples was determined using a PANalytical Axios and a PW2400 spectrometer. Samples were prepared by mixing with a flux material (Lithiummetaborate Spectroflux, Flux No. 100A, Alfa Aesar) and melting into glass beads. The beads were analyzed by wavelength dispersive $\mathrm{X}$-ray fluorescence spectrometry (WD-XRF). To determine loss on ignition (LOI) $1,000 \mathrm{mg}$ of sample material was heated to $1,030^{\circ} \mathrm{C}$ for $10 \mathrm{~min}$.

The cation exchange capacity (CEC) was measured using the $\mathrm{Cu}$-Triethylenetetramine method (Meier and Kahr 1999).

For electron optical investigations an environmental electron scanning microscope (ESEM) (Quanta 600F, FEI) operated at low-vacuum mode (0.6 mbar) was used. Therefore, sputtering of the samples with gold or carbon was not necessary. The microscope is equipped with the EDX-system Genesis 4000 of EDAX.

To measure midinfrared (MIR) spectra, the $\mathrm{KBr}$ pellet technique (1 mg of sample/200 mg of $\mathrm{KBr}$ ) was applied. Spectra with a resolution of $2 \mathrm{~cm}^{-1}$ were collected using a Thermo Nicolet Nexus FTIR spectrometer (MIR: beam splitter: $\mathrm{KBr}$, detector DTGS TEC).

Thermoanalytical investigations were performed using a Netzsch 409 PC thermobalance equipped with a DSC/TG sample holder linked to a Pfeiffer Thermostar quadrupole mass spectrometer (MS). $100 \mathrm{mg}$ of powdered material previously equilibrated at $53 \%$ relative humidity $(\mathrm{RH})$ was heated from 25 to $1,000^{\circ} \mathrm{C}$ with a heating rate of $10 \mathrm{~K} / \mathrm{min}$.

Total organic carbon (TOC) and sulfide/sulfate sulfur concentrations were measured with a LECO CS-444Analysator after dissolution of the carbonates. Carbonates had been removed by treating the samples several times at $80^{\circ} \mathrm{C}$ with $\mathrm{HCl}$ until no further gas evolution could be observed. Samples of $170-180 \mathrm{mg}$ of the dried material were used to measure the total carbon (TC) and S-content. TIC was calculated by the difference of TC-TOC. The samples were heated in the device to $1,800-2,000^{\circ} \mathrm{C}$ in an oxygen atmosphere and the $\mathrm{CO}_{2}$ was detected by an infrared detector. A depth profile of sample material with four subsamples from the weathered plate (surface to $5 \mathrm{~mm}, 5-10 \mathrm{~mm}, 10-15 \mathrm{~mm}, 15-20 \mathrm{~mm}=$ bottom) was analyzed for organic carbon and sulfate/sulfide sulfur concentrations using a C/S analyzer (CS-800, Eltra GmbH, 
Neuss). Pulverized sample material was taken for C/S analyses. $100 \mathrm{mg}$ of dried $\left(105^{\circ} \mathrm{C}\right)$ sample was mixed with $500 \mathrm{mg} \mathrm{Fe}$ and 1,000 mg W and subsequently catalytically combusted in an induction furnace in an oxygen atmosphere at about $1,400^{\circ} \mathrm{C}$. Carbon and sulfur were detected as $\mathrm{CO}_{2}$ and $\mathrm{SO}_{2}$, respectively, using an infrared absorption cell. Appropriate mixtures of quartz sand, $\mathrm{CaCO}_{3}$, and $\mathrm{Na}_{2} \mathrm{SO}_{4}$ were taken as calibration and quality control standards that were run after 10 sample measurements. The detection limit for both $\mathrm{C}$ and $\mathrm{S}$ was $0.01 \mathrm{wt} \%$. Inorganic carbon (IC) was analyzed as the difference between the total carbon (TC) content in a non-treated and a pre-treated ( $\mathrm{HCl} 25 \%)$ sample. The samples contained no IC. $100 \mathrm{mg}$ of dried $\left(105^{\circ} \mathrm{C}\right)$ sample was combusted without additives in an electric resistance oven in an oxygen atmosphere at $700^{\circ} \mathrm{C}$ and measured as $\mathrm{SO}_{2}$ in an infrared absorption cell. Appropriate mixtures of quartz sand and pyrite were used as calibration and quality control standards that were run after 10 sample measurements. The detection limit for $S_{\text {sulfide }}$ was $<0.25 \mathrm{wt} \%$. At the chosen temperature, complete $S_{\text {sulfide }}$ combustion takes place within a few minutes while $S_{\text {sulfate }}$ is still stable (Brumsack 1981). Assuming that all sulfur is present either as sulfide or sulfate in the sample, the sulfate content was calculated as the difference between $S_{\text {total }}$ and $S_{\text {sulfide. In each case, three subsamples }}$ were analyzed.

Mercury intrusion porosimetry was performed using a Carlo Erba mercury porosimeter (Porosimeter 2000). Total porosity and pore-size distribution were calculated from the volume of mercury pressed into the pore space as a function of pressure (Modry et al. 1981; van Brakel et al.

Table 1 VSI data set parameters

\begin{tabular}{lll}
\hline $\begin{array}{l}\text { Objective } \\
\text { magnification }\end{array}$ & $\begin{array}{l}\text { Field of view } \\
(\mu \mathrm{m} \times \mu \mathrm{m})\end{array}$ & $\begin{array}{l}\text { Virtual pixel length } \\
(\mathrm{nm})\end{array}$ \\
\hline $20 \times$ & $747 \times 747$ & 365 \\
$100 \times$ & $149 \times 149$ & 72 \\
\hline
\end{tabular}

1981). The investigations were carried out with pressures up to $2 \mathrm{kbar}$, which allows the evaluation of pore radii of about $4 \mathrm{~nm}$ (small mesopores). At least three specimens of every rock type were analyzed. The results show similar distributions for the respective rock type. Pore radii were calculated assuming cylindrical pore spaces (Ritter and Drake 1945a, b; Washburn 1921).

Vertical scanning interferometry: Surface topography variations of discolored versus dark-colored surface samples were examined using vertical scanning interferometry (VSI). A ZeMapper, manufactured by Zemetrics Inc., Tucson, AZ was used. VSI is an optical profilometry method that provides a large field of view of up to several $\mathrm{mm}^{2}$ and a high vertical resolution $(<1 \mathrm{~nm})$. For this study, white light interferometry mode was used. Two Mirau objectives (magnifications: $20 \times$ and $100 \times$ ) were utilized. The specifications of the three-dimensional data sets are given in Table 1. The obtained three-dimensional data sets were used for roughness parameter analysis. According to Fischer and Lüttge (2007), roughness parameters were analyzed as a function of field-of-view size. 24 data sets of discolored and dark-colored slate were analyzed, respectively.

\section{Results and discussion}

Petrography

\section{Results}

Surfaces of dark-colored slates are relatively smooth (Fig. 3, left part). Discolored slates show, however, a rough surface (Fig. 3, right part). Aggregates of fine-grained minerals at the surface of discolored slates form a fluffily and loosely structure. The dark-colored porphyroblasts are surrounded by fine-grained mineral aggregates. Thinsection microscopy of a rock profile confirms that the discolored slate surface has a porose structure (Fig. 4). The rock shows cracks and disaggregation parallel to the
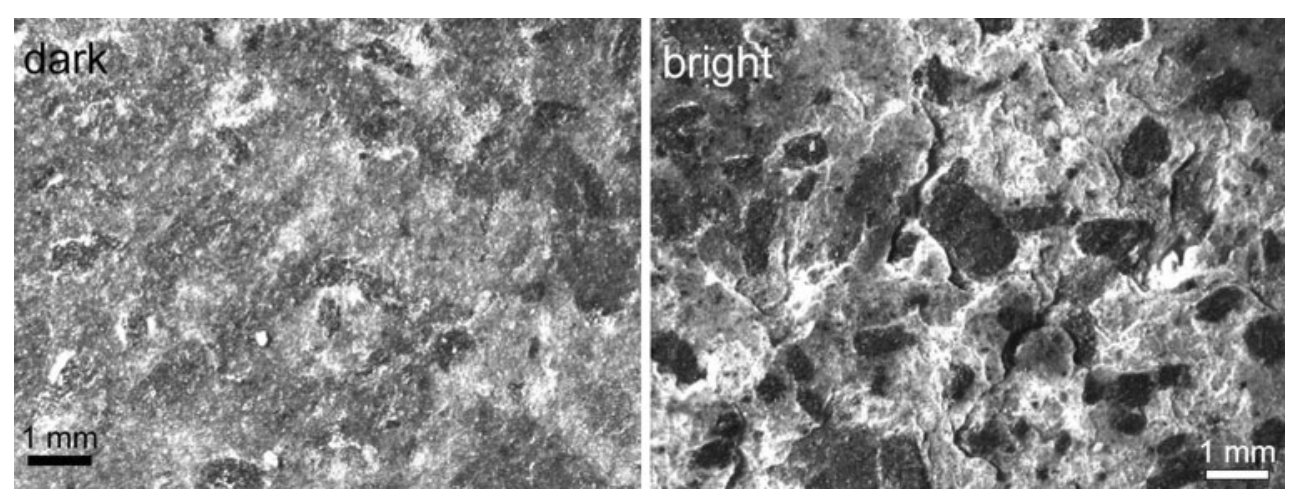

Fig. 3 Dark-colored slate (left) shows a smooth surface. Discolored (light-colored) slate (right) shows a rougher surface topography 


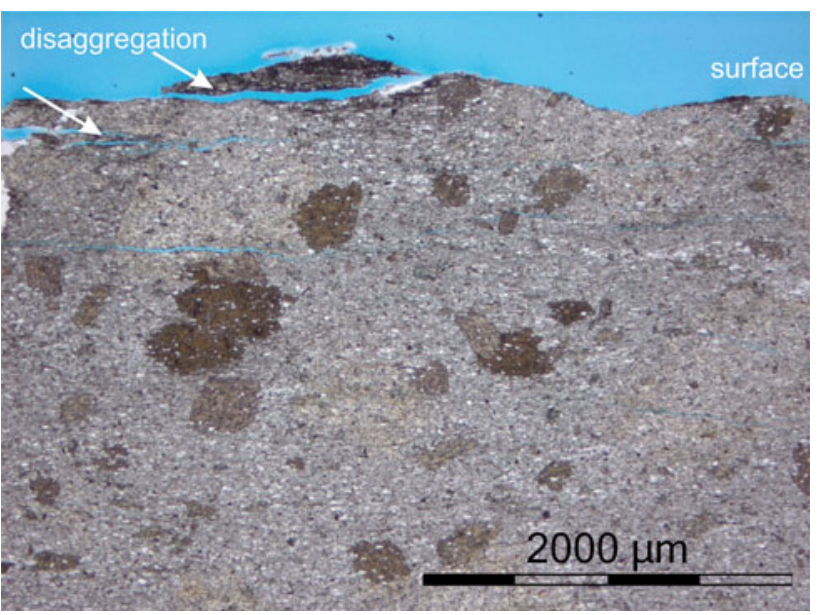

Fig. 4 Thin-section micrograph of a length profile through a plate of Fruchtschiefer building rock. The profile starts at the discolored surface (upper part), were disaggregated material is visible. Pore space is indicated by blue-colored resin

orientation of cleavage planes in the uppermost millimeter of the sample (the uppermost surface of thin-section sample in Fig. 4 is formed by a cleavage plane). The porphyroblasts have a green-brownish color, show slight pleochroism, and low birefringence.

\section{Discussion}

The comparison of the dark and bleached parts using optical microscopy proved a pronounced morphology (voids and valleys in Fig. 3, right) of the surface of the discolored sample. Such an alteration in morphology can be caused by mineral dissolution or by material disaggregation without material loss. Because the thin-section analysis shows the existence of cracks and loosening parallel to the cleavage planes of the rock, a simple material disaggregation is more likely. Thin-section analysis did also not show the evolution of secondary porosity due to complete or partial mineral dissolution. There was also no difference in mineralogical composition detected by thinsection analysis.

Mineralogy and Geochemistry

\section{Results}

X-ray diffraction patterns show for both black and discolored samples the occurrence of chlorite, illite/muscovite, albite, and quartz. No difference in mineralogy of the three sample types (dark bulk sample, dark surface sample, bleached/discolored sample) has been detected (Fig. 5). No cordierite was found. The cation exchange capacity (CEC) of all samples ranged from 1 to $2 \mathrm{meq} / 100 \mathrm{~g}$ with no systematic difference.
Table 2 Chemical composition analyzed by XRF measurements of three slate samples ( $S$ dark-colored surface sample, $D$ dark-colored bulk sample, $B$ bleached, discolored bulk sample)

\begin{tabular}{|c|c|c|c|c|c|c|c|}
\hline \multicolumn{4}{|c|}{ Main elements } & \multicolumn{4}{|c|}{ Trace elements } \\
\hline Sample & $\begin{array}{l}\text { P5-B } \\
\text { (mass\%) }\end{array}$ & $\begin{array}{l}\text { P5-D } \\
\text { (mass\%) }\end{array}$ & $\begin{array}{l}\text { P5-S } \\
\text { (mass\%) }\end{array}$ & Sample & $\begin{array}{l}\text { P5-B } \\
\text { (ppm) }\end{array}$ & $\begin{array}{l}\text { P5-D } \\
\text { (ppm) }\end{array}$ & $\begin{array}{l}\text { P5-S } \\
(\mathrm{ppm})\end{array}$ \\
\hline $\mathrm{SiO}_{2}$ & 59.6 & 61.3 & 61.1 & As & 3 & 3 & 3 \\
\hline $\mathrm{TiO}_{2}$ & 1.0 & 0.9 & 0.9 & $\mathrm{Ba}$ & 614 & 630 & 648 \\
\hline $\mathrm{Al}_{2} \mathrm{O}_{3}$ & 19.7 & 19.1 & 19.1 & $\mathrm{Bi}$ & 3 & $<3$ & $<3$ \\
\hline $\mathrm{Fe}_{2} \mathrm{O}_{3}$ & 7.8 & 7.6 & 7.4 & $\mathrm{Ce}$ & 72 & 112 & 89 \\
\hline $\mathrm{MnO}$ & 0.1 & 0.1 & 0.1 & Co & 18 & 14 & 17 \\
\hline $\mathrm{MgO}$ & 2.0 & 1.7 & 1.7 & $\mathrm{Cr}$ & 91 & 89 & 86 \\
\hline $\mathrm{CaO}$ & 0.3 & 0.2 & 0.2 & Cs & 21 & 18 & 17 \\
\hline $\mathrm{Na}_{2} \mathrm{O}$ & 1.1 & 1.1 & 1.1 & $\mathrm{Cu}$ & 17 & 13 & 14 \\
\hline $\mathrm{K}_{2} \mathrm{O}$ & 3.8 & 3.9 & 3.9 & $\mathrm{Ga}$ & 26 & 25 & 25 \\
\hline $\mathrm{P}_{2} \mathrm{O}_{5}$ & 0.1 & 0.1 & 0.1 & $\mathrm{Hf}$ & $<7$ & $<7$ & $<7$ \\
\hline$\left(\mathrm{SO}_{3}\right)$ & 0.0 & $<0.01$ & 0.0 & $\mathrm{La}$ & 37 & 49 & 54 \\
\hline (Cl) & 0.0 & 0.1 & 0.1 & Mo & $<3$ & $<3$ & $<3$ \\
\hline (F) & $<0.05$ & $<0.05$ & $<0.05$ & $\mathrm{Nb}$ & 22 & 20 & 21 \\
\hline LOI & 4.4 & 3.7 & 4.1 & $\mathrm{Nd}$ & 27 & 24 & 27 \\
\hline \multirow[t]{16}{*}{ Sum } & 99.7 & 99.7 & 99.7 & $\mathrm{Ni}$ & 44 & 40 & 45 \\
\hline & & & & $\mathrm{Pb}$ & 18 & 17 & 18 \\
\hline & & & & $\mathrm{Rb}$ & 188 & 188 & 190 \\
\hline & & & & $\mathrm{Sb}$ & $<7$ & $<7$ & 8 \\
\hline & & & & $\mathrm{Sc}$ & 15 & 16 & 16 \\
\hline & & & & $\mathrm{Sm}$ & 31 & 19 & $<17$ \\
\hline & & & & $\mathrm{Sn}$ & $<4$ & $<4$ & $<4$ \\
\hline & & & & $\mathrm{Sr}$ & 95 & 90 & 94 \\
\hline & & & & $\mathrm{Ta}$ & $<5$ & $<5$ & $<5$ \\
\hline & & & & Th & 15 & 16 & 20 \\
\hline & & & & $\mathrm{U}$ & $<4$ & $<4$ & $<4$ \\
\hline & & & & $\mathrm{V}$ & 103 & 105 & 111 \\
\hline & & & & W & $<5$ & $<5$ & $<5$ \\
\hline & & & & $\mathrm{Y}$ & 40 & 39 & 39 \\
\hline & & & & $\mathrm{Zn}$ & 111 & 108 & 114 \\
\hline & & & & $\mathrm{Zr}$ & 191 & 206 & 190 \\
\hline
\end{tabular}

Left three columns: main element concentrations, right three columns: trace element concentrations

X-ray fluorescence analysis of the three samples showed similar concentrations of main and trace elements of the samples (Table 2). Small differences are within the range of accuracy and should not be interpreted further. No noticeable high concentrations of trace elements were found (Table 2).

Analysis of organic carbon and sulfur concentrations (Tables 3, 4) showed almost no $\mathrm{C}$ and $\mathrm{S}$ content of the samples. The discolored samples are free of organic carbon and the dark gray-colored samples contain only very minor concentrations of organic carbon (Table 3). The black surface material (sample P5 S, Table 3) shows organic 
Fig. 5 XRD pattern of the three (powder) samples: $S$ darkcolored surface sample, $D$ darkcolored bulk sample, $B$ bleached, discolored bulk sample

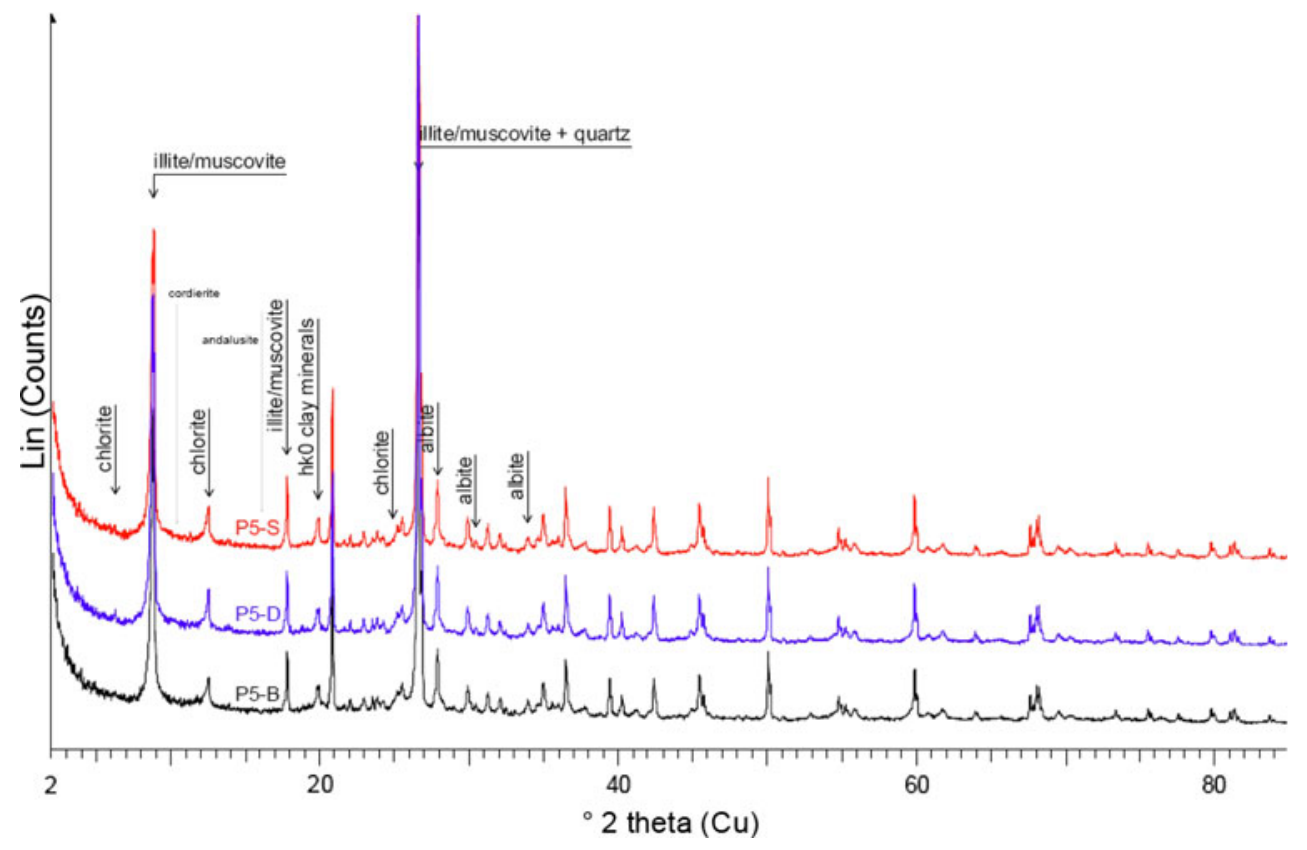

carbon concentration close to the detection limit. The depth profile of a discolored sample (Table 4, left column) confirmed these findings: the organic carbon concentration is generally very low over the profile. A slightly higher C concentration was found at the surface of the discolored sample. This variation is, however, close to the limit of uncertainty of the analysis. Thermal treatment of samples was performed to check for sulfate versus sulfide sulfur occurrence. The concentration of total sulfur of the

Table 3 Carbon and sulfur concentrations of three slate samples ( $S$ dark-colored surface sample, $D$ dark-colored bulk sample, $B$ bleached, discolored bulk sample)

\begin{tabular}{lllll}
\hline Sample & $\begin{array}{l}C_{\text {total }} \\
(\text { mass\% })\end{array}$ & $\begin{array}{l}C_{\text {org }} \\
(\text { mass\%) }\end{array}$ & $\begin{array}{l}C_{\text {inorg }} \\
(\text { mass\%) }\end{array}$ & $\begin{array}{l}S_{\text {total }} \\
\text { (mass\%) }\end{array}$ \\
\hline P5 B & 0.0 & 0.0 & 0.0 & 0.1 \\
P5 D & 0.0 & 0.0 & 0.0 & 0.0 \\
P5 S & 0.1 & 0.1 & 0.0 & 0.0 \\
\hline
\end{tabular}

Table 4 Carbon and sulfur analysis of a depth profile (rock surface: discolored)

\begin{tabular}{llll}
\hline $\begin{array}{l}\text { Depth profile } \\
(\mathrm{mm})\end{array}$ & \multicolumn{2}{l}{ Untreated samples } & $\begin{array}{l}\text { Thermal treatment } \\
\left(700^{\circ} \mathrm{C}\right)\end{array}$ \\
\cline { 2 - 3 } & $\mathrm{C}(\mathrm{ppm})$ & $S_{\text {total }}(\mathrm{ppm})$ & \begin{tabular}{l}
$S_{\text {sulfate }}(\mathrm{ppm})$ \\
\hline $0-5$
\end{tabular} \\
\hline $5-10$ & 350 & 50 & 0 \\
$10-15$ & 300 & 0 & 0 \\
$15-20$ & 250 & 0 & 0 \\
\hline
\end{tabular}

uppermost profile section (Table 4 , sample $0-5 \mathrm{~mm}$ ) is very low and close to the detection limit. After thermal treatment, no sulfate sulfur was detected.

Because of the potentially very low concentration of organic matter in the slate samples, thermoanalytical and infrared spectroscopic analyses were performed to verify the previous findings. Thermal analysis when combined with a mass spectrometer (DTA-MS) is particularly sensitive towards S- and C-phases. The MS-C data proved the absence of carbonates. The surface sample (PBS) shows, however, a slightly elevated organic carbon content which is also evident from the DSC curve (Fig. 6).

The data indicate also for the DSC curve the dehydroxylation of the clay minerals and the phase transition of quartz. The DTA-MS-SO $\mathrm{S}_{2}$ curve proves the presence of minor amounts of sulfate in the bleached sample. In addition, in the DSC curve a small peak at $120^{\circ} \mathrm{C}$ was observed which falls within the dehydration range and was only observed in the case of the bleached sample. This peak possibly can be attributed to the dehydration of gypsum.

Analogous to XRD no mineralogical difference of the samples was found by IR. However, a slightly larger intensity of the $\mathrm{CH}$ stretching vibrations being typical of organic matter, were found in the sample from the dark surface (Fig. 7), hence confirming the LECO and DTAdata.

Back-scatter electron (BSE) images of dark and bright section of the slate were compared (Fig. 8). The border between the dark and bright parts of the plate of sample P5 SEM was marked with a pencil. The pencil mark is dark in the BSE image because the back scatter electron detector is 
sensitive towards heaviness and density of the minerals and elements. Therefore, the pencil mark and organic material appear dark in the BSE image and the minerals consisting of heavier elements (e.g., iron bearing minerals) are brighter. The dark part shows numerous dark spots $(10-100 \mu \mathrm{m})$ which were identified as organic matter using the EDX (Fig. 8a, c, e). In the bleached part much less organic matter was observed (Fig. 8a, b, d), which is in good agreement with LECO, DTA (Fig. 6), and IR (Fig. 7) data. In the bleached part, additionally morphological steps were observed, which is in accordance with the light optical observations. The porphyroblasts (Fig. 4) which led to the term "Fruchtschiefer" (translated: "fruit slate") consist of mica (biotite and muscovite), chlorite, and some quartz. The mica within these aggregates is perfectly parallel-oriented to the longitudinal axis of each inclusion (Fig. 8).

\section{Discussion}

According to Kaufhold et al. (2002) the CEC can be used for the estimation of the content of swellable clay minerals
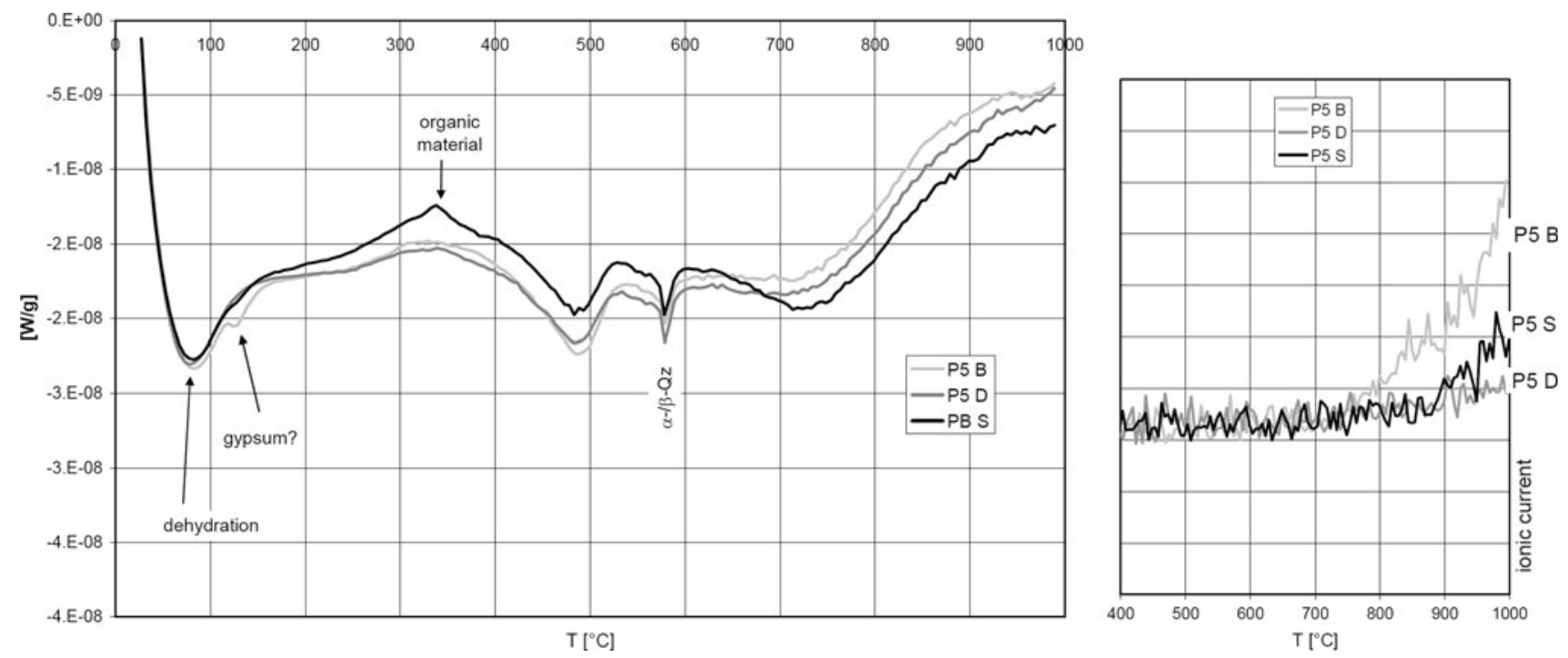

Fig. 6 Thermoanalytical data of three slate samples ( $S$ dark-colored surface sample, $D$ dark-colored bulk sample, $B$ bleached, discolored bulk sample); left: DSC data; right: $\mathrm{MS}^{-\mathrm{SO}_{2}}$ data

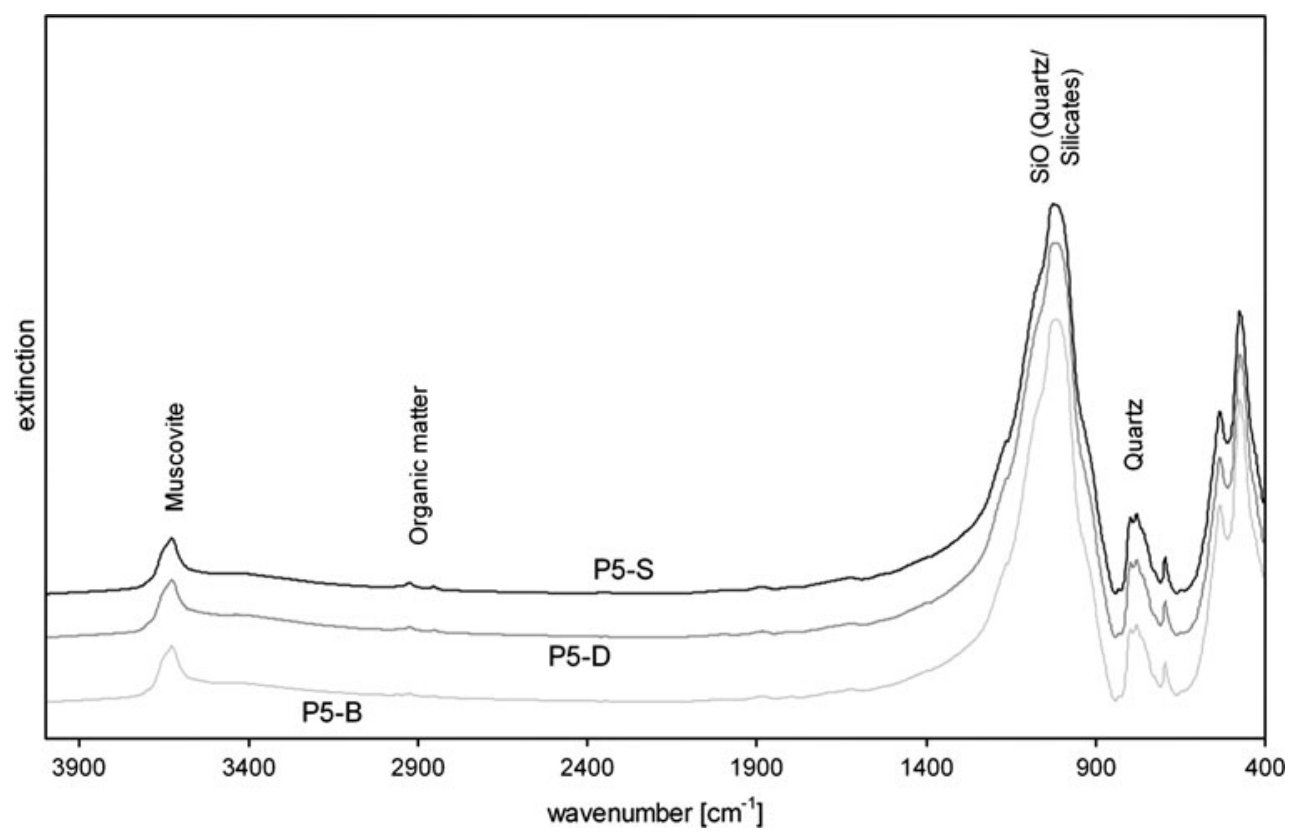

Fig. 7 Infrared spectroscopic data: $S$ dark-colored surface sample, $D$ dark-colored bulk sample, $B$ bleached, discolored bulk sample 
which, accordingly, is supposed to be around $1 \mathrm{wt} \%$ in the case of the samples of the present study and probably represents swellable layers of illite-smectite mixed-layers rather than isolated smectites. However, no systematic difference of the $\mathrm{CEC} /$ content of swellable clay minerals was found.

No noticeable high concentrations of trace elements were found. This also suggests the lack of (mature) organic matter in all samples. Ordinarily, organic matter-bearing black slates show anomalous high concentrations of trace elements, e.g., REE, or uranium (e.g., Lev et al. 1998). Both sample types, discolored and dark-colored slate contain no sedimentary organic carbon and no diagenetic sulfide/sulfate sulfur. Even very low sedimentary organic carbon concentrations at the detection limit are not able to cause the observed changes in color. From several studies about color change of black slates during oxidative
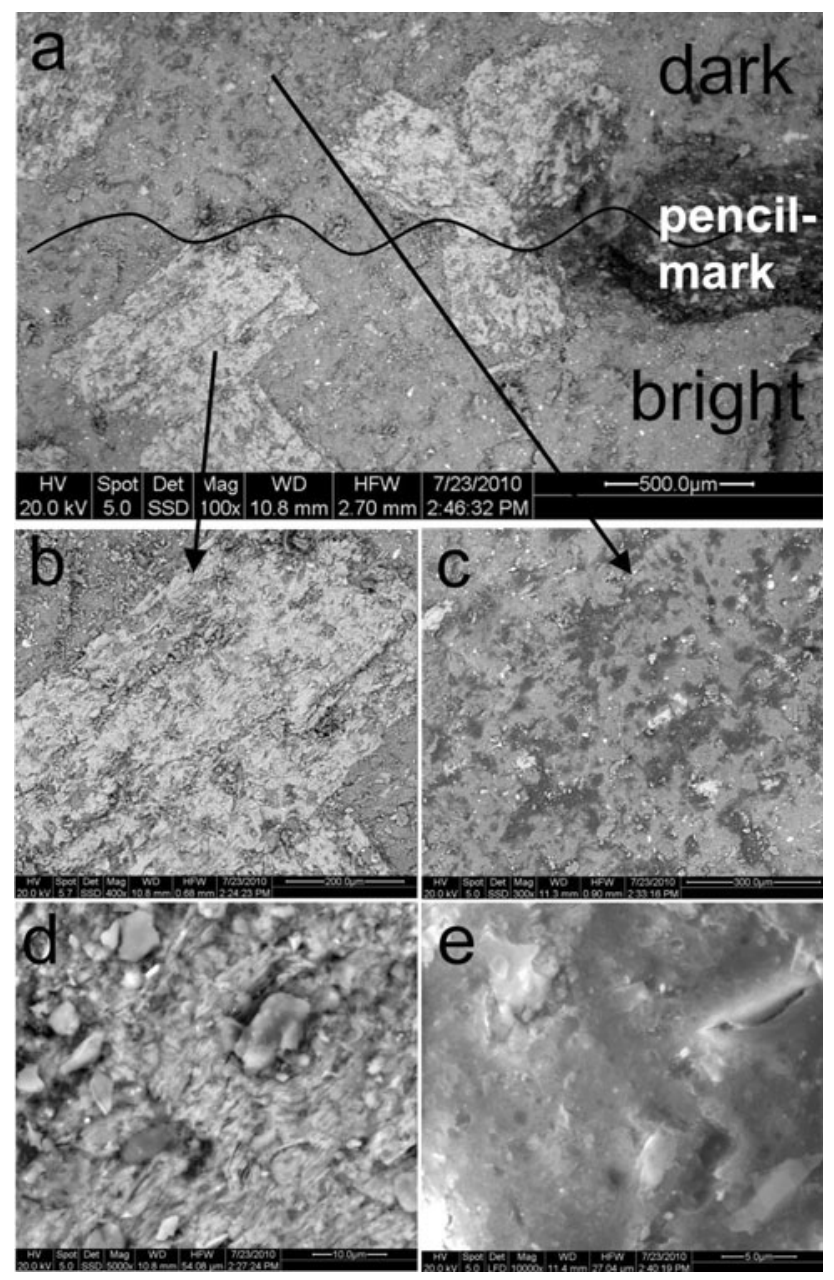

Fig. 8 Electron micrographs of a transition zone (a) of a darkcolored to light-colored section of plate 5 recorded with the back scatter electron detector (BSE). The dark part is further investigated in $\mathbf{c}$ and e (only image with secondary electron detector), and the bright part is further investigated in $\mathbf{b}$ and $\mathbf{d}$ removal of organic carbon it is known that the change from dark-colored to bright-colored rock material requires organic matter concentration changes from $>2 \mathrm{wt} \%$ to approx. $1 \mathrm{wt} \%$.

On the other hand, in the present case the organic matter was found to occur as an incomplete coating, i.e., spots of $10-300 \mu \mathrm{m}$ in diameter (dark areas in the ESEM image, Fig. 8c). The larger organic carbon content of the dark surface compared to the bulk material and the outer parts was proved by LECO (Table 3), DTA-MS (Fig. 6), IR (Fig. 7), and ESEM (Fig. 8). All methods, however, prove that the organic carbon content is rather low, although only the surface was sampled. ESEM investigations of some organic spots revealed different organic particles with different shapes and different densities which raises the question about the source of the organic material, which could not be proved. The organic material could represent dirt or soot that accumulated over the years of exposition. Also a thin film of living OM (microbiological origin, algae, etc.) is a possible source for such a thin surface cover.

The reason for the splitting off of the surface at the outer parts could not be identified. One could speculate that it is related to a volume increase reaction which could be the swelling of swellable clay minerals or the formation of new mineral phases. CEC measurements proved the low content of swellable layers and no difference between the different samples. LECO and DTA-MS, on the other hand, proved a slightly larger sulfate content at the outer parts which proves that $\mathrm{S}$ entered the outer parts of the plates and precipitated as gypsum. If this small amount of gypsum ( $0.1 \mathrm{wt} \% \mathrm{~S}$ corresponds to approximately $0.5 \mathrm{wt} \%$ gypsum) actually caused the splitting off the organic patina remains an open question.

\section{Porosity and surface roughness}

\section{Results}

Discolored and dark gray sample material was investigated by mercury intrusion porosimetry (Fig. 9). Dark gray slate total porosity is about $1.9 \mathrm{vol} \%$. The discolored rock material has a porosity of about $8.2 \mathrm{vol} . \%$. For analysis of the discolored rock, only material of the uppermost part of the weathered rock plate was used (first part of depth profile $(0-5 \mathrm{~mm})$, see "Material and methods" section). Pore size histogram of black material shows a rather uniform distribution (Fig. 9, upper part). There is, however, a maximum in the histogram graph showing the predominance of small mesopores (IUPAC 1985). Discolored slates show a pore size distribution with a maximum of pores with radii of about $1-25 \mu \mathrm{m}$. An increase in frequency is observed for pore radii above $25 \mathrm{~nm}$ (macropores). Mesopores do not contribute to the increase in total porosity. 
Fig. 9 Histogram of pore size distribution of dark-colored (upper part) and discolored (lower part) Fruchtschiefer slate. Total porosity and pore size distribution were analyzed by mercury intrusion method. Minimum pore radius is $4 \mathrm{~nm}$, maximum pore radius is $63 \mu \mathrm{m}$
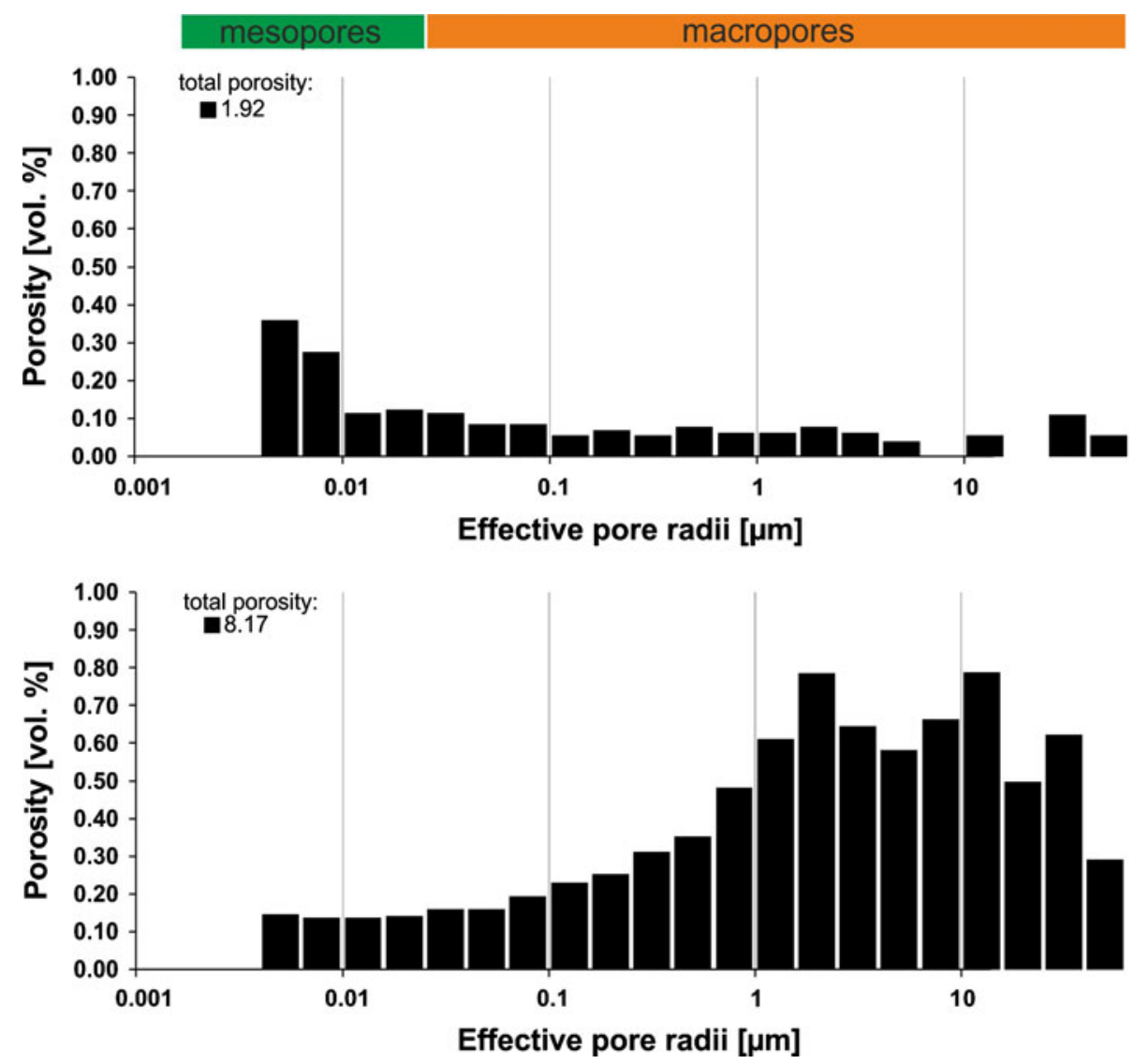

Vertical Scanning Interferometry (VSI) data are able to provide information about surface topography variations over a large field-of-view. Figure 9 provides information about the topography of dark gray slates versus discolored slates. A surface section without porphyroblasts was chosen to analyze potential topography alterations of fine-grained mineral aggregates between porphyroblasts. Petrographic observations underline the discoloration of the material in-between porphyroblasts (Figs. 3, 4). Data subsets and profile lines (Fig. 10b, c, e, f) show the general differences in surface topography: The dark gray rock surface is relatively smooth and shows variations in topography in the submicron range. The discolored rock surface shows a higher variability in surface topography. The height range is several microns. Quantitative data about surface roughness variations are shown in Fig. 11. The root-mean-square roughness $R q$ is a robust parameter to quantify height (amplitude) variations (Dong et al. 1992, 1994a). Roughness data are shown as a function of field-of-view length to detect the impact of lateral size of amplitude variations (Dong et al. 1994b; Fischer and Lüttge 2007). Root mean square roughness data show a stable difference for field lengths $>10 \mu \mathrm{m}$. The roughness difference is caused by the surface deviations visualized in Fig. 10b and e. The surface factor $F$ data (Fig. 11b) indicate a remarkable increase in surface area due to disaggregation (discoloration). Compared to dark gray slates $(F<1.5)$, the discolored slates show an increase in total surface area by factor 2 or $3 \quad(F=2-3)$. Figure 11c confirms the robustness of roughness data: The increase in $R z$ over length $(l)$ shows the potential impact of surface deviations like single deep pores, etc. However, independently of such singular surface deviations of several micron in depth, both $R q$ and $F$ data show no outliers (Fig. 11a, b).

\section{Discussion}

The broad distribution of newly formed pores (25 $\mathrm{nm}<r<25 \mu \mathrm{m})$ in discolored slates indicates rather a disaggregation of the rock or of mineral aggregates than dissolution of a mineral phase. As an example, the dissolution of high-rank organic matter and iron sulfides results in changes of the pore size distribution of a much more smaller range than indicated by the above data, see for comparison Fischer and Gaupp (2005). We conclude that also the pore size data support the interpretation that dissolution of sedimentary OM or diagenetically formed sulfide is not the reason for the observed rock color change of the building rocks. 
Fig. 10 Vertical scanning interferometry (VSI) data of dark-colored (left column, a-c) vs. discolored slate (right column, $\mathbf{d}-\mathbf{f}$ ) surfaces. Upper row: Height maps of surface sections, size is $149 \mu \mathrm{m} \times$ $149 \mu \mathrm{m}$. Central part: A data subset (size: $15 \mu \mathrm{m} \times 15 \mu \mathrm{m}$ ) shows the characteristic surface topography deviations of both sample types. No surface of porphyroblasts is included in this subset. A profile over both topographies compares surface topography differences
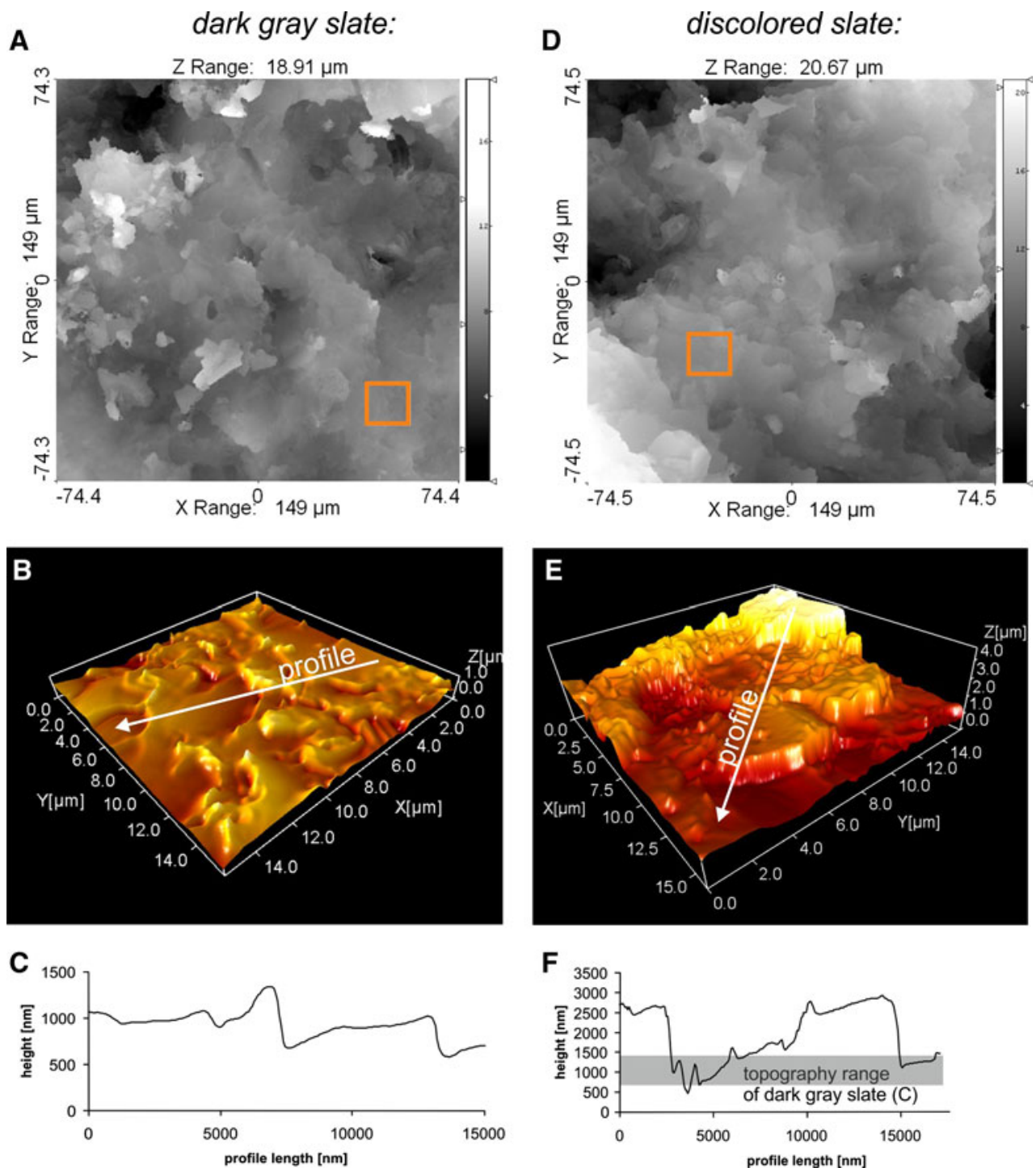

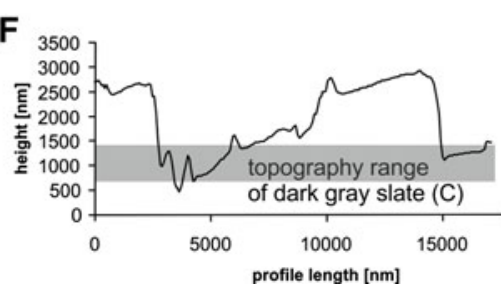

Surface roughness data of dark and discolored slate surfaces sampled by VSI revealed an increase in surface roughness for discolored rock sections. Discolored surface sections show an increase in surface topography variation of several microns. The rather uniform and smooth surface of dark gray slates changed to a rougher surface of discolored slates. The roughness data confirm the interpretation about material disaggregation. The increase in roughness in the micron range does, however, show that the disaggregation is rather low. The Fruchtschiefer slate is a very stable material and the observed surface changes are just visible due to discoloration. No material loss or significant loosening or breaking-up of material was observed. The change in color/brightness can be explained similar to the strike color of minerals: Transparent sheet silicates (like muscovite) show a bright, white strike color. This bright color is the color under reflected light of smallgrained mineral powder. The structure of the mineral powder is similar to the here observed disaggregated, porous rock surfaces with higher surface roughness.

\section{Conclusions}

Weathering of Fruchtschiefer building rocks from Theuma (Sachsen, Germany) is rather a rock disaggregation than dissolution of rock components. Close to the edges of building blocks, the discoloration indicates an increase in surface roughness and porosity close to the surface. The disaggregation is limited to the uppermost $1-2 \mathrm{~mm}$ of the rock. This also underlines the high stability against weathering of this rock type. Surface topography analysis by vertical scanning interferometry is able to provide information about roughness alteration over a large fieldof-view and therefore is a valuable tool for surface analysis of weathered building rock surfaces. Roughness parameter 

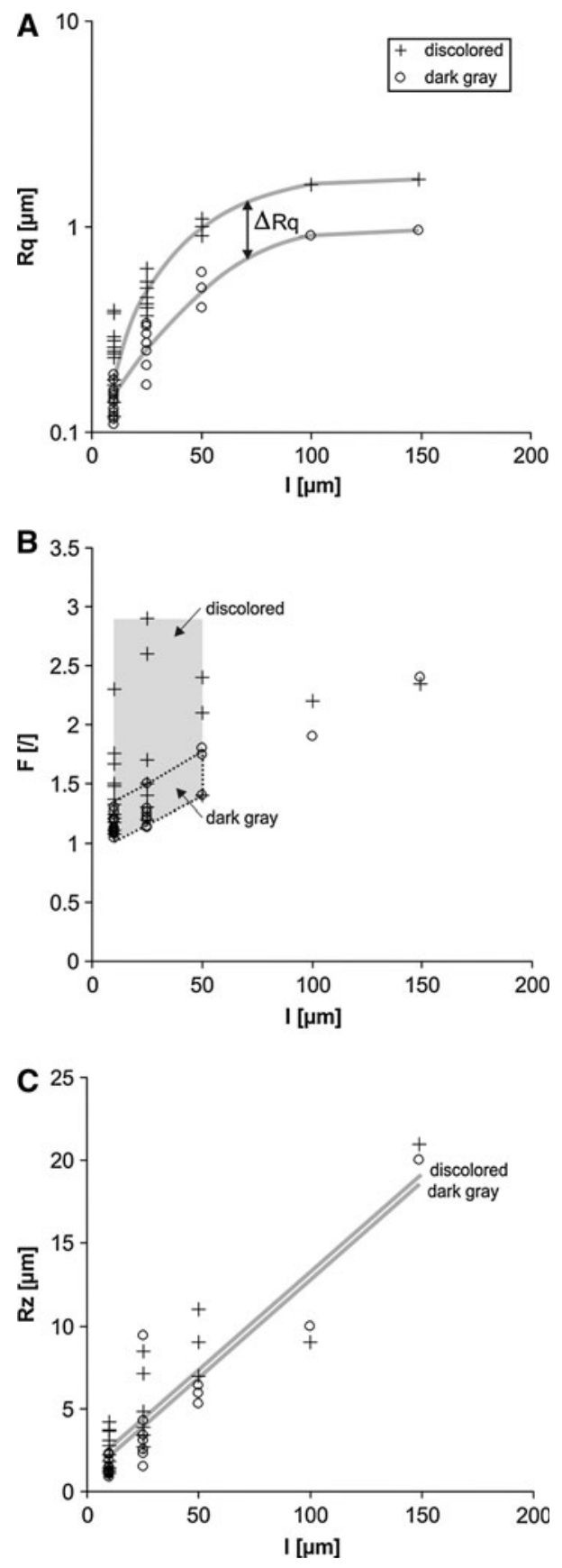

Fig. 11 Surface roughness parameter analysis of dark gray and discolored slate surfaces. Root-mean-square roughness $R q$ (a), surface factor $F(\mathbf{b})$, and peak-peak height $R z$ (c) are shown

analysis as a function of field-of-view length (so-called converged roughness parameters) proves the impact of rock components to the overall roughness variation and provides information about differences in stability against weathering of the rock surface.

Mineralogical and chemical analysis proved that the difference in color (dark-colored vs. bright-colored) of the rock surface is partly caused by a thin cover (thickness $\ll 1 \mathrm{~mm}$ ) of recent organic matter, located at the surface of the dark parts and the exfoliation of such covers at light-colored surface sections. The existence of such covers was proved by several mineralogical and chemical methods. However, the discoloration of the uppermost millimeters of building blocks (Fig. 1d) can not be explained by this phenomenon. The data presented here also suggest that removal of sedimentary OM is not responsible for discoloration.

As reported from several buildings, the intensity of discoloration may vary under similar weathering conditions. This indicates differences in the resistance against weathering and disaggregation. The here discussed disaggregation close to the edges of building blocks might be initiated or enhanced due to cleaving and sawing of the rock panels. Differences in mechanical load during manufacturing of building blocks could result in different initial material stress at trimmed edges. Later ingress of moisture and subsequent freeze-thawing-cycles as well as salt crystallization could then be responsible for the here reported disaggregation and increase in rock surface roughness, indicated by discoloration.

Acknowledgments We thank an anonymous reviewer for helpful comments and suggestions. This work was in part supported by a grant (\# 03G0719A) of the Geotechnologien R\&D program of BMBF and DFG to CF.

Open Access This article is distributed under the terms of the Creative Commons Attribution Noncommercial License which permits any noncommercial use, distribution, and reproduction in any medium, provided the original author(s) and source are credited.

\section{References}

Brumsack HJ (1981) A simple method for the determination of sulfide-sulfur and sulfate-sulfur in geological materials by using different temperatures of decomposition. Fresenius Zeitschrift für Analytische Chemie 307:206-207

Dong WP, Sullivan PJ, Stout KJ (1992) Comprehensive study of parameters for characterizing 3-dimensional surface-topography. 1. Some inherent properties of parameter variation. Wear 159:161-171

Dong WP, Sullivan PJ, Stout KJ (1994a) Comprehensive study of parameters for characterizing 3-dimensional surface-topography. 3. Parameters for characterizing amplitude and some functionalproperties. Wear 178:29-43

Dong WP, Sullivan PJ, Stout KJ (1994b) Comprehensive study of parameters for characterizing 3-dimensional surface-topography. 4. Parameters for characterizing spatial and hybrid properties. Wear 178:45-60

Falk F, Wiefel H (1995) Ordovizium. In: Seidel G, (ed) Geologie von Thüringen: Stuttgart, E. Schweizerbart'sche Verlagbuchhandlung, pp 91-110

Fischer C, Gaupp R (2005) Change of black shale organic material surface area during oxidative weathering: implications for rockwater surface evolution. Geochim Cosmochim Acta 69:12131224 
Fischer C, Lüttge A (2007) Converged surface roughness parameters-a new tool to quantify rock surface morphology and reactivity alteration. Am J Sci 307:955-973

Fischer C, Karius V, Thiel V (2007) Organic matter in black slates shows oxidative degradation within only a few decades. J Sed Res 77:355-365

Fischer C, Schmidt C, Bauer A, Gaupp R, Heide K (2009) Mineralogical and geochemical alteration of low-grade metamorphic black slates due to oxidative weathering. Chemie der Erde-Geochemistry 69:127-142

Forster HJ, Tischendorf G, Trumbull RB, Gottesmann B (1999) Latecollisional granites in the Variscan Erzgebirge, Germany. J Petrol 40:1613-1645

Gaitzsch B, Steinbach V, Kampe A, Wolf P (2008) Baueinheiten des Molassestockwerkes: 3.4 Spätvariszischer Magmatismus. In: Pälchen W, Walter H, (eds) Geologie von Sachsen: Stuttgart, E. Schweizerbart'sche Verlagsbuchhandlung

Gerstenberger H, Haase G, Wemmer K (1995) Isotope systematics of the Variscan postkinematic granites in the Erzgebirge (E Germany): Terra Nostra, Extended Abstracts of the 2nd Symposium on Permocarboniferous Igneous Rocks

IUPAC (1985) Reporting physisorption data for gas/solid systems. Pure Appl Chem 57:603-619

Kaufhold S, Dohrmann R, Ufer K, Meyer FM (2002) Comparison of methods for the quantification of montmorillonite in bentonites. Appl Clay Sci 22:145-151

Lev SM, McLennan SM, Meyers WJ, Hanson GN (1998) A petrographic approach for evaluating trace-element mobility in a black shale. J Sed Res 68:970-980

Linnemann U, Heuse T (2000) The Ordovician of the Schwarzburg anticline: geotectonic setting, biostratigraphy and sequence stratigraphy Saxo-Thuringian Terrane, Germany. Z Dt Geol Ges 151(4):471-491

Littke R, Klussmann U, Krooss B, Leythaeuser D (1991) Quantification of loss of calcite, pyrite, and organic-matter due to weathering of Toarcian black shales and effects on kerogen and bitumen characteristics. Geochim Cosmochim Acta 55:3369-3378
Matthes S (1990) Chapter C. 2: Die Kontaktmetamorphose an Plutonen. Mineralogie, Berlin, Springer, pp 316-320

Meier LP, Kahr G (1999) Determination of the cation exchange capacity (CEC) of clay minerals using the complexes of copper(II) ion with triethylenetetramine and tetraethylenepentamine. Clays Clay Miner 47:386-388

Modry S, Svata M, van Brakel J (1981) Thematic bibliography of mercury porosimetry: powder technology 29:13-43

Pälchen W, Walter H (2008) Geologie von Sachsen: Geologischer Bau und Entwicklungsgeschichte. Schweizerbart'sche Verlagsbuchhandlung, Stuttgart, p 537

Peschel A, Franz E (1968) Spotted Schists of Theuma (Vogtland) Relations between Genesis and Utilization. Zeitschrift Fur Angewandte Geologie 14:483

Petsch ST, Berner RA, Eglinton TI (2000) A field study of the chemical weathering of ancient sedimentary organic matter. Org Geochem 31:475-487

Ritter HL, Drake LC (1945a) Pore size distribution in porous materials. I. Pressure porosimeter and determination of complete macropore size distributions. Ind Eng Chem Anal Edn 17:782-786

Ritter HL, Drake LC (1945b) Pore size distribution in porous materials. II. Macropore size distributions in some typical porous substances. Ind Eng Chem Anal Edn 17:787-791

Siedel H, Siegesmund S (2011) Characterisation of stone deterioration on buildings. In: Snethlage R, Siegesmund S (eds) Stone in architecture. Springer, Berlin, Heidelberg, pp 347-410

Siegesmund S, Snethlage R (2011) Stone in architecture. Springer, Berlin, Heidelberg

van Brakel J, Modry S, Svata M (1981) Mercury porosimetry-state of the art. Powder Technol 29:1-12

Washburn EW (1921) The dynamics of capillary flow. Phys Rev Ser 2:273-283

Zimmerle W, Stribrny B (1992) Organic carbon-rich pelitic sediments in the Federal Republic of Germany: Courier Forschungsinstitut Senckenberg, v. 152: Frankfurt a. M., p 142 